"Non-performing financing of Islamic rural bank industry in Indonesia"

\begin{tabular}{|c|c|}
\hline AUTHORS & $\begin{array}{l}\text { Muhamad Nadratuzzaman Hosen (D https://orcid.org/0000-0001-5958-8564 } \\
\text { Syafaat Muhari (D https://orcid.org/0000-0002-0750-6886 }\end{array}$ \\
\hline ARTICLE INFO & $\begin{array}{l}\text { Muhamad Nadratuzzaman Hosen and Syafaat Muhari (2019). Non-performing } \\
\text { financing of Islamic rural bank industry in Indonesia. Banks and Bank Systems, } \\
\text { 14(1), 20-28. doi:10.21511/bbs.14(1).2019.03 }\end{array}$ \\
\hline DOI & http://dx.doi.org/10.21511/bbs.14(1).2019.03 \\
\hline RELEASED ON & Tuesday, 15 January 2019 \\
\hline RECEIVED ON & Wednesday, 13 June 2018 \\
\hline \multirow[t]{2}{*}{ ACCEPTED ON } & Wednesday, 19 December 2018 \\
\hline & $($ (c) EY \\
\hline LICENSE & $\begin{array}{l}\text { This work is licensed under a Creative Commons Attribution } 4.0 \text { International } \\
\text { License }\end{array}$ \\
\hline JOURNAL & "Banks and Bank Systems" \\
\hline ISSN PRINT & $1816-7403$ \\
\hline ISSN ONLINE & $1991-7074$ \\
\hline PUBLISHER & LLC “Consulting Publishing Company "Business Perspectives" \\
\hline FOUNDER & LLC “Consulting Publishing Company "Business Perspectives" \\
\hline
\end{tabular}

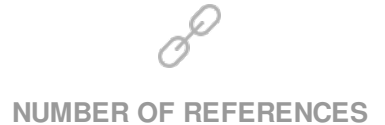

14

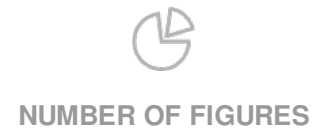

0
NUMBER OF TABLES

2

(C) The author(s) 2023. This publication is an open access article. 


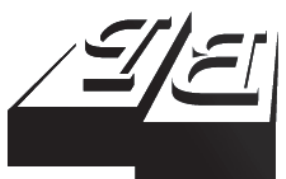

BUSINESS PERSPECTIVES

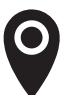

LLC "CPC "Business Perspectives" Hryhorii Skovoroda lane, 10, Sumy, 40022, Ukraine

www.businessperspectives.org

Received on: $13^{\text {th }}$ of June, 2018 Accepted on: $19^{\text {th }}$ of December, 2018

(c) Muhamad Nadratuzzaman Hosen, Syafaat Muhari, 2019

Muhamad Nadratuzzaman Hosen, Ph.D., Senior Lecturer, State Islamic University of Syarif Hidayatullah Jakarta, Indonesia.

Syafaat Muhari, Master of Economics, Lecturer, Institute for Qur'anic Studies, Jakarta, Indonesia.

\section{NON-PERFORMING FINANCING OF ISLAMIC RURAL BANK INDUSTRY IN INDONESIA}

\begin{abstract}
This study is aimed at analyzing the financial performance and indicator of macroeconomics to influence the quality of financing at Islamic Rural Bank Industry (IRBI) in Indonesia. The panel data regression is used to predict the change of quality of financing which is reflected by value of non-performing financing (NPF). The model of this study is grouped by four areas of working zones because IRBI has different competency depending on its region. The sample of the study used 72 IRBIs in the periods of Quarter II 2010 to Quarter I 2016. The results of the study show that simultaneously, variables for the size of banks, financing to deposit ratio (FDR), operational efficiency ratio (OER), return on equity (ROE), expense to assets (EA), percentage of gross domestic product (GDP), and the rate of inflation are statistically significant to nonperforming financing of the IRBI in Indonesia. GDP has strongly significant impact on the NPF of IRBI in Indonesia. According to Areas of working zones, inflation has quite significant impact on the IRBI in Zone One, and GDP has strongly significant impact on the IRBI in Zone Two, Zone Three, and Zone Four. Nevertheless, there are different effects of GDP towards NPF which has a negative impact on Zone One and Zone Four, meanwhile Zone Two and Zone Three have a positive impact. In conclusion, government policy treatment should be different at every zone.
\end{abstract}

\section{Keywords Islamic rural banks, non-performing financing, areas of working zones, panel data regression}

JEL Classification E50, G21

\section{INTRODUCTION}

The purpose of the establishment of Islamic Rural Bank Industry (IRBI) is to serve small scale entrepreneurs in both rural and suburban areas which are not generally covered by commercial banks. IRBI is forbidden to conduct business activities as commercial banks like opening check accounts and participation in national clearing system. Furthermore, IRBI is prohibited to conduct businesses for doing foreign exchange and for financing equity fund (Buchori, Himawan, Setijawan, \& Rohmah, 2003).

In general, IRBI has similar purposes and characteristics to several Micro-Finance Institutions (MFIs). IRBI has two main objectives to be achieved at once, namely commercial and community development. This means that IRBI is not only for getting profit but also for serving community (The World Bank, 2013, pp. 2-3).

Based on data from the Financial Services Authority (FSA), there are 167 IRBIs in Indonesia supported by 441 offices and 4.619 employees until December 2017. The total assets of IRBI in Indonesia at December 2017 are Rp. 10.24 trillion and the Third Party Funds (TPF) are Rp. 6.98 trillion. IRBIs are managing 1.38 millions of deposits account and 293 thousands of loan accounts from their assets as at December 2017. The rapid growth of the number of IRBIs is in line with the growth of assets, financing and funding as a results of the issuance of Law Number 28 at 2008. 
The financing of IRBI is quite risky with regard to slowing growth of IRBI activities as a result of slowing growth of economy since 2013. One of the methods to measure the quality of the financing is to measure the Non-Performing Financing (NPF) (Bloem \& Gorter, 2001, p. 4).

In Indonesia, IRBIs have different business environment and conditions with regard to each location and geographic condition. Thus, Financial Services Authority (FSA) or Otoritas Jasa Keuangan (OJK), is issuing POJK No. 20/POJK.03/2014 about the new rules of IRBI activities. In the new POJK, FSA makes four grouping zones related to different levels of competency.

Zone 1 is located in a big suburban area with the highest potential economy and tight financial activities of competitions. Furthermore, Zone 4 is located in a small town or in rural area with the lowest potential economy and slight financial activities of competitions. These four zones have differences for each core capital, namely core capital of zone 1 is set at Rp. 14 billion, zone 2 is set at Rp. 8 billion, zone 2 is set at Rp. 6 billion, and zone 4 is set at Rp. 4 billion. Therefore this research uses NPF model based on national zone and four zones of IRBI working areas related to Regulation of Financial Services Authority in Indonesia No. 20/POJK.03/2014.

The value of NPF at IRBI is an important issue to be discussed because the value of NPF is related to the quality of financing from customers to IRBI. The poor quality of assets may have an impact on the level of net margin in financing, then impact on the profitability of the IRBI because there are nonproductive funds which must be reserved to anticipate financing risks. The study about the level of NPF in Islamic Rural Bank Industries is relatively limited. This study analyzed the effect of bank-specific factors such as bank size, efficiency, profitability, and liquidity, and the effect of macroeconomic factors like percentage of GDP and rate of inflation on the level of NPF in Islamic Rural Bank Industry in Indonesia. Moreover, the novelty of this study is to analyze the change of the level of NPF based on four zones in Indonesia where each zone has different characteristics.

\section{LITERATURE REVIEW}

The study about the value of NPF in IRBI can be explained. Some indicators are set to be independent variables which affect NPF. The independent variables consist of bank specific factors (bank size, efficiency, profitability, and liquidity) and macroeconomic factors (GDP growth and inflation rate).

To standardize the measurement of non-performing loans/non-performing financing among the countries, the Institute of International Finance (IIF) classified the quality of loan/quality of financing into five collectabilities, namely standard, watch, substandard, doubtful, and loss (Bloem \& Gorter, 2001, pp. 6-7). Financing or Loan is categorized as non-performing when it is reporting as collectability of substandard, doubtful, and loss.

One of the bank specific factors that could affect the level of NPF in IRBI is a Bank Size. Louzis, Vouldis, and Metaxas (2012) state that banks with a bigger size have more opportunities of loan diversification in order to reduce NPF. On the other hand, Firmansyah (2014) found that there was no effect of size on the level of NPF.

Bank's Efficiency may also be related with the level of NPF. However, Firmansyah (2014) stated that there was no effect of the level of efficiency on the NPF level. Zaini Abd Karim, Chan, and Hassan (2010), Berger and DeYoung (1997), and Espinoza and Prasad (2010) concluded that the lower level of efficiency could escalate the level of NPF. Consequentlty, the level of cost efficiency is an important indicator of bad quality loans.

The study from Berger and DeYoung (1997) and Zaini Abd Karim, Chan, and Hassan (2010) proved that bad quality of management could escalate bad quality loans. Meanwhile, Espinoza and Prasad (2010) expressed a belief that higher profitability of banks described better managed banks which contributed to minimizing the NPF level. 
Another bank specific factor that could affect the level of NPF is liquidity. Firmansyah (2014) who used proxy of Financing to Deposit ratio (FDR) concluded that liquidity positively affected the level of NPF. Although Espinoza and Prasad (2010) used a different proxy (Expense to Assets/EA), this study showed a similar result as well.

In addition to bank specific factors, percentage of GDP and level of inflation are the external variables that could affect the level of NPF. The study conducted by Firmansyah (2014), Klein (2013), Espinoza and Prasad (2010), Skarica (2014), and Endut, Syuhada, Ismail, and Mahmood (2013) stated that low level of economic growth which can be seen from the percentage of GDP could escalate the level of NPF. Whereas the effect of the inflation rate on the level of NPF is positive, a study by Firmansyah (2014), Klein (2013), and Skarica (2014) proved that high rate of inflation could increase the level of NPF.

\section{RESEARCH METHOD}

\subsection{Research design}

The design of this research is a quantitative research. This study is using multiple regression model with panel data. This study adopts the NPF model by Firmansyah (2014), who examines the factors influencing NPF of IRBI in Indonesia and employs independent variables based on the study by Klein (2013) and Espinoza and Prasad (2010). The NPF model in this study can be divided into four models which refer to working zone areas as defined by Regulation of Financial Services Authority in Indonesia No. 20/POJK.03/2014. The independent variables which affect the level of NPF are presented in Table 1.

\subsection{Research variables}

The variables used in this study consist of dependent and independent variables. The dependent variable is the value of $N P F$ which is one of indicators to measure Quality of Financing of Islamic Rural Bank Industry (IRBI). Meanwhile, the independent variables are natural logarithm of bank size (LNTA), ratio of financing to deposit ratio (FDR), operating expenses ratio $(O E R)$, ratio of return on equity $(R O E)$, ratio of expenses to assets $(E A)$, percentage of gross domestic product $(G D P)$, and the rate of inflation (INF).

Sources of data are the financial statements of IRBI in the period of Quarter II 2011 to Quarter 12016 published on the official website of the Central Bank of Indonesia. The number of total series data of each IRBI is 20 quarters and the number of total population of IRBI in this study until March 2016 is 165. Further, the purposive sampling method was used in this study. Criteria of the sample is the number of Islamic Rural Banks which publish the complete financial statements during the period of study. Based on these criteria, there are 72 IRBIs which spread out from zone one to zone four.

\subsection{Econometric methodology}

\subsubsection{Estimation with pooled OLS}

Gujarati (2003, pp. 61-62) suggests that the principle or the method of least squares chooses $\hat{\beta}_{1}$ and $\hat{\beta}_{2}$ in such a manner that, for a given sample or set of data, $\sum \hat{u}_{i}^{2}$ is as small as possible. In

Table 1. NPF model by working zones

\begin{tabular}{|c|c|c|}
\hline Sign & Independent variables & Sources \\
\hline LN_TA & $\begin{array}{l}\text { Ln_ASET (Logarithm of natural total assets) is represented by } \\
\text { bank size }\end{array}$ & Klein (2013) \\
\hline FDR & FDR (Financing to Deposit Ratio) is represented by liquidity & Firmansyah (2014) \\
\hline OER & OER (Operational Expenses Ratio) is represented by efficiency & $\begin{array}{l}\text { Firmansyah (2014), Berger and Young (1997), Karim } \\
\text { et al. (2010) }\end{array}$ \\
\hline EA & $\begin{array}{l}\text { EA (Total Expenses to Total Assets) is represented by } \\
\text { efficiency }\end{array}$ & Espinoza and Prasad (2010) \\
\hline ROE & ROE (Return on Equity) is represented by profitability & Klein (2013) \\
\hline GDP & $\begin{array}{l}\text { GDP (Gross Domestic Product) is represented by precentage/ } \\
\text { growth of Gross Domestic Product }\end{array}$ & $\begin{array}{l}\text { Firmansyah (2014), Klein (2013), Endut et al. (2013), } \\
\text { Skarica (2014) }\end{array}$ \\
\hline INF & INF (Inflation) is represented by the inflation rate & $\begin{array}{l}\text { Firmansyah (2014), Klein (2013), Endut et al. (2013), } \\
\text { Skarica (2014) }\end{array}$ \\
\hline
\end{tabular}


other words, for a given sample, the method of least squares provides us with unique estimates of $\hat{\beta}_{1}$ and $\hat{\beta}_{2}$ that give the smallest possible value of $\sum \hat{u}_{i}^{2}$. The process of differentiation yields the following equations for estimating $\beta_{1}$ and $\beta_{2}$ :

$$
\begin{gathered}
\sum Y_{i}=n \hat{\beta}_{1}+\beta_{2} \sum X_{i}, \\
\sum Y_{i} X_{i}=\hat{\beta}_{1} \sum X_{i}+\beta_{2} \sum X_{i}^{2},
\end{gathered}
$$

where $n$ is the sample size.

These simultaneous equations are known as the normal equations. Solving the normal equations simultaneously, then obtain:

$$
\begin{aligned}
& \hat{\beta}_{2}=\frac{n \sum X_{i} Y_{i}-\sum X_{i} \sum Y_{i}}{n \sum X_{i}^{2}-\left(\sum X_{i}\right)^{2}}= \\
& =\frac{\sum\left(X_{i}-\bar{X}\right)\left(Y_{i}-\bar{Y}\right)}{\sum\left(X_{i}-\bar{X}\right)^{2}}=\frac{\sum x_{i} y_{i}}{\sum x_{i}^{2}},
\end{aligned}
$$

where $\hat{X}$ and $\hat{Y}$ are the sample means of $X$ and $Y$ and where it can be defined

$$
x_{i}=\left(X_{i}-\ddot{X}\right), \quad y_{i}=\left(Y_{i}-\ddot{Y}\right) \text {. }
$$

Henceforth, the convention of letting the lowercase letters can be adopted that denote deviations from mean values.

$$
\hat{\beta}_{1}=\frac{\sum X_{i}^{2} \sum Y_{i}-\sum X_{i} \sum X_{i} Y_{i}}{n \sum X_{i}^{2}-\left(\sum X_{i}\right)^{2}}=\bar{Y}-\bar{\beta}_{2} \bar{X} .
$$

The last step can be obtained by simple algebraic manipulations. The estimators acquired earlier are known as the least-squares estimators, for they are derived from the least-squares principle. Note the following numerical properties of estimators acquired by the OLS method: "Numerical properties are those that hold as a consequence of the use of ordinary least squares, regardless of how the data were generated".

\subsubsection{The fixed effects model}

The term of fixed effects is because of the fact that, albeit the intercept may differ across individuals, each individual's intercept does not vary in course of time; that is, it is time invariant. Notice that if the intercept is written as $\beta_{1 i t}$, it will suggest that the intercept of each company or individual is time variant. It can be easily done by the dummy variable technique, particularly the differential intercept dummies (Gujarati, 2003, p. 642). Therefore, it can be written as (Gujarati, 2003):

$$
\begin{aligned}
& Y_{i t}=\alpha_{1}+\alpha_{2} D_{2 i}+\alpha_{3} D_{3 i}+ \\
& +\alpha_{4} D_{4 i}+\beta_{2} X_{2 i t}+\beta_{3} X_{3 i t}+u_{i t},
\end{aligned}
$$

where $D_{2 i}=1$ if the observation belongs to $X_{2}, 0$ otherwise; $D_{3 i}=1$ if the observation belongs to $X_{3}$, 0 otherwise. Since we are using dummies to estimate the fixed effects in the model. It is also known as the least-squares dummy variable (LSDV) model. Thus, the terms of fixed effects and LSDV can be used interchangeably. In passing, note that the LSDV model is also known as the covariance model and $X_{2}$ and $X_{3}$ are known as covariates (Gujarati, 2003, p. 642).

\subsubsection{The random effects model}

If the dummy variables do in fact show a lack of knowledge about the true model, this is definitely the approach suggested by the advocates of the so called error components model (ECM) or random effects model (REM) (Gujarati, 2003, p. 647). What we are actually saying is that the seventy two firms included in our sample are drawn from a much larger universe of such companies and that they have a common mean value for the intercept $\left(=\beta_{1}\right)$ and the individual discrepancies in the intercept values of each company are shown in the error term $\varepsilon_{i}$. Then it can be obtained (Gujarati, 2003):

$$
\begin{aligned}
& Y_{i t}=\beta_{1}+\beta_{2} X_{2 i t}+\beta_{3} X_{3 i t}+\varepsilon_{i}+u_{i t}= \\
& =\beta_{1}+\beta_{2} X_{2 i t}+\beta_{3} X_{3 i t}+w_{i t},
\end{aligned}
$$

where $w_{i t}=\varepsilon_{i}+u_{i t}$.

The composite error term $w_{i t}$ contains two components, $\varepsilon_{i}$, which is the cross-section, or individual-specific, error component, and $u_{i t}$, which is the combined time series and cross-section error component. The term error components model derives its name due to the fact that the composite error term $w_{i t}$ consists of two (or more) error components. The usual suppositions made by ECM are (Gujarati, 2003): 


$$
\begin{gathered}
\varepsilon_{i} \sim N\left(0, \sigma_{\varepsilon}^{2}\right), \\
u_{i t} \sim N\left(0, \sigma_{u}^{2}\right), \\
E\left(\varepsilon_{i} u_{i t}\right)=0, E\left(\varepsilon_{i} \varepsilon_{j}\right)=0, \quad(i \neq j), \\
E\left(u_{i t} u_{i s}\right)=E\left(u_{i t} u_{j t}\right)=E\left(u_{i t} u_{j s}\right)=0, \\
(i \neq j ; t \neq s),
\end{gathered}
$$

that is, the individual error components are not correlated with each other and are not autocorrelated across both cross-section and time series units. However, $\varepsilon_{i}$ is not directly visible; it is what is known as an unobservable, or latent, variable (Gujarati, 2003, p. 648).

\subsubsection{The method of weighted least squares}

To illustrate the method, Gujarati (2003, p. 437438) uses the two-variable model

$$
Y_{i}=\beta_{1}+\beta_{2} X_{i}+u_{i}
$$

The unweighted least-squares method minimizes:

$$
\sum \hat{u}_{i}^{2}=\sum\left(Y_{i}-\hat{\beta}_{1}-\hat{\beta}_{2} X_{i}\right)^{2},
$$

to acquire the estimates, whereas the weighted least-squares method minimizes the weighted residual sum of squares:

$$
\sum w_{i} \hat{u}_{i}^{2}=\sum w_{i}\left(Y_{i}-\hat{\beta}_{1}^{*}-\hat{\beta}_{2}^{*} X_{i}\right)^{2},
$$

where $\hat{\beta}_{1}^{*}$ and $\hat{\beta}_{2}^{*}$ are the weighted least-squares estimators and where the weights $w_{i}$ are such that:

$$
w_{i}=\frac{1}{\sigma_{i}^{2}} .
$$

That is, the weights are conversely proportional to the variance of $u_{i}$ or $Y_{i}$ conditional upon the given $X_{i}$, it being understood that

$$
\operatorname{var}(u i / X i)=\operatorname{var}(Y i / X i)=\sigma_{i}^{2} .
$$

Differentiating with respect to $\beta_{1}^{*}$ and $\beta_{2}^{*}$, the following can be obtained:

$$
2 \sum w_{i}\left(Y_{i}-\hat{\beta}_{1}^{*}-\hat{\beta}_{2}^{*} X_{i}\right)(-1)
$$

$$
\frac{\partial \sum w_{i} \hat{u}_{i}^{2}}{\partial \beta_{2}^{*}}=2 \sum w_{i}\left(Y_{i}-\hat{\beta}_{1}^{*}-\hat{\beta}_{2}^{*} X_{i}\right)\left(-X_{i}\right)
$$

Making the preceding expressions equal to zero, the following two normal equations can be obtained:

$$
\begin{gathered}
\sum w_{i} Y_{i}=\hat{\beta}_{1}^{*} \sum w_{i}+\hat{\beta}_{2}^{*} \sum w_{i} X_{i}, \\
\sum w_{i} X_{i} Y_{i}=\hat{\beta}_{1}^{*} \sum w_{i} X_{i}+\hat{\beta}_{2}^{*} \sum w_{i} X_{i}^{2} .
\end{gathered}
$$

Notice the similitude between these normal equations and the normal equations of the unweighted least squares. Solving these equations concurrently, one can obtain:

$$
\hat{\beta}_{1}^{*}=\bar{Y}^{*}-\hat{\beta}_{2}^{*} \bar{X}^{*}
$$

and

$$
\hat{\beta}_{2}^{*}=\frac{\left(\sum w_{i}\right)\left(\sum w_{i} X_{i} Y_{i}\right)-\left(\sum w_{i} X_{i}\right)\left(\sum w_{i} Y_{i}\right)}{\left(\sum w_{i}\right)\left(\sum w_{i} X_{i}^{2}\right)-\left(\sum w_{i} X_{i}\right)^{2}} .
$$

Note:

$$
\bar{Y}^{*}=\sum w_{i} Y_{i} / \sum w_{i} \text { and } \bar{X}^{*}=\sum w_{i} X_{i} / \sum w_{i} .
$$

As can be readily verified, these weighted means coincide with the usual or unweighted means $\bar{Y}$ and $\bar{X}$ when $w_{i}=w$, a constant for all $i$.

\subsubsection{Model specification}

Then the model for each zone in this study can be defined as follows:

$$
\begin{aligned}
& N P F_{i t}=\alpha+b_{1} L N_{-} T A_{i t}+b_{2} F D R_{2 i t}+ \\
& +b_{3} O E R_{3 i t}+b_{4} E A_{4 i t}+b_{5} R O E_{5 i t}+ \\
& +b_{6} G D P_{6 i t}+b_{7} I N F_{7 i t}+\varepsilon_{i},
\end{aligned}
$$

where $\alpha$ is an intercept, $i$ is cross-section data, $t$ is time-series data, NPF (Non-Performing Financing) is represented by Quality of Financing, $L n_{-} T A$ (Logarithm of natural total assets) is represented by a bank size, FDR (Financing to Deposit Ratio) is represented by liquidity, OER (Operational Expenses Ratio) and EA (Total Expenses to Assets) are represented by efficiency, ROE (Return on Equity) is represented by profitability, GDP (Gross Domestic Product) is represented by precentage/growth of Gross Domestic Product, and INF (Inflation) is represented by inflation rate. 
Variables of LNTA, FDR, OER, EA, and ROE are represented by bank specific factors, and variables of GDP and INF are represented by macroeconomic factors.

\section{EMPIRICAL RESULTS}

The results of the four estimation methods can be seen in Table 2.

\subsection{Zone one}

The economic model is good when it is statistically and economically accepted. From Table 2 it can be defined that the WLS model is the best in zone one, because F-stat is accepted and $R^{2}$ is the highest (98.95\%). Furthermore, all of the variables except $E A$ are statistically accepted.

Size of banks which are represented by total assets $(T A)$ has significant positive influence on the value of NPF in IRBI in zone one which was locat- ed in the major suburban area of Indonesia. Most of the composition in IRBI assets came from financing, so whenever the size of banks dramatically increases, the value of NPF increases as well. Therefore, this indicates that risk management in financing of IRBI is not optimal to minimize non-performing financing.

$F D R$ ratio has a significant positive influence on the level of NPF in IRBI in zone one. This indicates that the increase in financing spent by IRBI in zone one can increase the level of NPF. In fact, the increase in zone one of financing may not be compensated by good risk management hence the level of NPF increases in line with financing.

The ratio of $O E R$ and $E A$ indicated the efficiency level of IRBI, the high ratio of OER indicated that IRBI does not operate efficiently. OER ratio has a significant positive influence on the level of NPF in IRBI in zone one. Consequently, IRBI in zone one must operate efficiently and increase the profitability to reduce the value of NPF.

Table 2. NPF model by working zones

\begin{tabular}{|c|c|c|c|c|c|c|c|c|c|c|}
\hline Model & C & LNTA & FDR & OER & EA & ROE & GDP & INF & R-Sq & $\mathbf{F}$ \\
\hline \multicolumn{11}{|c|}{ Zone One } \\
\hline OLS & $0.709^{*}$ & $-0.031^{*}$ & $-0.118^{*}$ & 0.011 & 0.245 & -0.030 & 0.346 & -0.301 & $19.96 \% *$ & $8.09^{* *}$ \\
\hline FEM & -0.434 & 0.031 & 0.000 & 0.019 & 0.137 & $-0.072 *$ & 0.417 & -0.37 & $73.60 \% *$ & $31.89^{* *}$ \\
\hline REM & -0.254 & 0.020 & -0.001 & 0.020 & 0.131 & $-0.070^{*}$ & 0.374 & -0.334 & $34.83 \% *$ & $16.19^{* *}$ \\
\hline WLS & $0.131^{*}$ & $0.486^{*}$ & $0.111^{*}$ & $0.011^{*}$ & -0.181 & $-0.181^{*}$ & $-0.136^{*}$ & $0.589 *$ & $98.95 \% *$ & $12.18^{* *}$ \\
\hline \multicolumn{11}{|c|}{ Zone Two } \\
\hline OLS & $0.223^{*}$ & $-0.008^{*}$ & $0.025^{*}$ & $-3.2 \mathrm{e}-010$ & $0.122 *$ & $-0.118^{*}$ & 0.022 & 0.150 & $15.41 \% *$ & $23.35^{* *}$ \\
\hline FEM & $0.293^{*}$ & $-0.009 *$ & $-0.036^{*}$ & $-1.10 \mathrm{e}-08$ & $0.120^{*}$ & $-0.094^{*}$ & 0.124 & 0.142 & $38.21 \% *$ & $19.81^{* *}$ \\
\hline REM & $0.285^{*}$ & $-0.009 *$ & $-0.028^{*}$ & $-8.9 e-09$ & $0.118^{*}$ & $-0.097^{*}$ & 0.107 & 0.146 & $73.42 \%$ & $399.98 * *$ \\
\hline WLS & $0.220^{*}$ & -0.040 & $0.017^{*}$ & $0.030^{*}$ & $0.011^{*}$ & 0.042 & $0.053^{*}$ & -0.222 & $90.75 \% *$ & $29.62^{* *}$ \\
\hline \multicolumn{11}{|c|}{ Zone Three } \\
\hline OLS & 0.126 & $-0.010^{*}$ & $0.082 *$ & $0.062 *$ & 0.075 & -0.028 & 0.044 & 0.175 & $23.98 \% *$ & $7.27^{* *}$ \\
\hline FEM & -0.311 & 0.020 & 0.052 & -0.010 & -0.025 & -0.060 & 0.087 & 0.269 & $66.47 \% *$ & $19.21^{* *}$ \\
\hline WLS & 0.062 & $0.027^{*}$ & -0.015 & 0.025 & $-0,220$ & 0.055 & $0.237^{*}$ & -0.132 & $81.84 \% *$ & $5.94^{* *}$ \\
\hline \multicolumn{11}{|c|}{ Zone Four } \\
\hline OLS & $0.707^{*}$ & $-0.032^{*}$ & $-0.051^{*}$ & $-7.6 e-08$ & -0.009 & $-0.197^{*}$ & -0.085 & -0.014 & $23.77 \% *$ & $11.65^{* *}$ \\
\hline FEM & 0.561 & -0.023 & $-0.054^{*}$ & $-2.0 e-08$ & $-0.169^{*}$ & $-0.125^{*}$ & -0.169 & 0.140 & $59.54 \% *$ & $18.07^{* *}$ \\
\hline REM & $0.686^{*}$ & $-0.030^{*}$ & $-0.056^{*}$ & $-2.4 \mathrm{e}-08$ & $-0.158^{*}$ & $-0.133^{*}$ & -0.181 & 0.145 & $42.61 \%$ & $26.36^{* *}$ \\
\hline WLS & $0.844^{*}$ & -0.069 & -0.084 & -0.029 & -0.462 & $-0.075^{*}$ & $-0.498^{*}$ & $0.317^{*}$ & $44.69 \% *$ & $18.17^{* *}$ \\
\hline
\end{tabular}

Note: Dependent variable: non-performing financing. ${ }^{*}$ means independent variables significant at 5\%; ${ }^{* *}$ F-test significant at $5 \%$. 
Percentage of GDP has a significant negative influence on the level of NPF in zone one. Zone one as a big suburban area in Indonesia is a main business area in the industrial and commercial field where these two sectors are main factors which encourage economic activities. Consequently, the economic downturn could hit industrial and commercial sectors most of which establish cooperation with banking sectors including IRBI. Then banks or IRBI are hit by a significant increase in value of NPF because they find the difficulties when collect debt or financing from customers.

The rate of inflation has a significant positive influence on the level of NPF in zone one. Weak economic growth leads to sluggish economic activity in the industrial, commercial and agricultural sectors, thereby reducing the profit of debtors applying for financing at the IRBI. A decrease in profit from IRBI debtors will increase the risk profile of the debtors so that the more severe in paying the financing.

Inflation has a positive and significant effect on the level of NPF in IRBI in zone one. One of the negative impacts of inflation is reducing purchasing power of consumer including banks or IRBI customers, especially for customers who apply for debt or financing.

\subsection{Zone two}

The economic model is good when it is statistically and economically accepted. From Table 2 it can be defined that the WLS model is the best in zone two, because F-stat is accepted and $R^{2}$ is the highest (90.75\%). Furthermore, all of the variables except for $R O E$ are statistically accepted.

Similarly with zone one, IRBI in zone two is located in suburban area as well but the suburban area is not as big as zone one. Size of banks, which are represented by total assets (TA), has a significantly positive influence on the value of NPF in IRBI in zone two. Most of the composition in IRBI assets came from financing. Whenever the size of banks dramatically increases, the value of $N P F$ increases as well. Therefore, this indicated that risk management in financing of IRBI is not optimal to minimize non-performing financing. The result also proves the hypothesis of bad man- agement proposed by Berger and DeYoung (1997) that poor management in the banking institutions leads to bad quality loans and increases the level of non-performing loans.

The FDR ratio has a significantly positive influence on the NPF levels in IRBI in zone two. This indicates that the increase in financing spent by IRBI in zone two can increase the level of NPF. In fact, it can be stated that the increase in financing in zone two is not compensated by good risk management, so the level of NPF increases in line with financing.

$O E R$ and $E A$ ratio has a significant positive influence on the level of NPF in IRBI in zone two. Consequently, IRBI in zone one must operate efficiently and increase the profitability to reduce the value of NPF. Similarly with zone one, zone two is located in a big suburban area where IRBIs struggle to compete with many commercial banks and non-bank financial institutions which offered more completed and convenient products than the IRBIs.

Economic growth represented by a percentage of $G D P$ has a significant positive influence on the level of NPF in IRBI in zone two. The GDP effect on the value of NPF in zone two is different from that of zone one. The results from zone one suggest that the financing customers are unable to meet their obligations to bank because of the economic downturn. Meanwhile the result from zone two suggests that the financing customers are unable to meet their obligations to bank because of the economic upturn.

Faiz (2010) stated that the increasing NPF can occur when debt or financing grows significantly as a result of high economic growth. The results from the GDP positive effect on the value of NPF is similar with variables of $T A$ and FDR. Indeed, IRBIs in zone two have to improve risk management in financing in order to keep the value of NPF low.

\subsection{Zone three}

The economic model is good when it is statistically and economically accepted. Although the OLS model has more significant independent variables but $R^{2}$ is very low (23.98\%). From Table 2 it can be defined that the WLS model is the best in zone 
three, because F-stat is accepted and $R^{2}$ is the highest (81.84\%). Furthermore, variables of $T A$ and GDP are statistically accepted.

Zone three is located in small Town on Java Island and Sumatra Island, and sub-urban are on the Kalimantan Island and Sulawesi Island. Size of banks, which are represented by total assets (TA), has a significantly positive influence on the value of $N P F$ in IRBI in zone two. Most of the composition in IRBI assets came from financing. Whenever the size of banks dramatically increases, the value of NPF increases as well. Therefore, this indicated that risk management in financing of IRBI is not optimal to minimize non-performing financing in zone three.

Similar with zone two, economic growth represented by the percentage of GDP has a significant positive influence on the level of NPF in IRBI in zone two. The GDP effect on value of NPF in zone two is different from zone one. The result from zone one suggests that the financing customers are unable to meet their obligations to bank because of the economic downturn. Meanwhile the result from zone two suggests that the financing customers are unable to meet their obligations to bank because of the economic upturn.

The performance of IRBI in zone two and zone three should be better than in zone one, because the competition among financial institutions in zone two and zone three is not as tight as in zone one. Then IRBI in zone one and zone two should maximize the role of risk committee by enhancing the capability of members. The high capability of human resources is needed to increase the level of risk mitigation. The quality of human resources from IRBI is one of the major problems which should be fixed in order to maintain the good performance of IRBIs.

\subsection{Zone four}

The economic model is good when it is statistically and economically accepted. Although the OLS model has more significant independent variables but $R^{2}$ is very low (23.77\%). From Table 2 it can be defined that the FEM model is the best in zone four, because F-stat is accepted and $R^{2}$ is the highest (59.54\%). Furthermore, variables of TA and GDP are statistically accepted. In conclusion, based on the data estimation, WLS model is the best to estimate the level of NPF in every zone, except for zone four.

Zone four is located in a small Town in the Eastern Indonesia, including part of Sulawesi Island, The Molucca Islands, The Lesser Sunda Islands, and Papua Island. The table shows that the FDR ratio has a significant negative influence on the level of $N P F$ in IRBI in zone four. The result shows us that the level of $N P F$ can raise when the ratio of FDR decreases, so IRBI in zone one needs to increase the financing portfolio in order to reduce the level of NPF. Unfortunately, zone four is an economically undeveloped area compared with other zones.

The ratio of $E A$ and $R O E$ indicated the efficiency level and profitability level of IRBIs. The high ratio of OER indicated that IRBI do not operate efficiently, then the high ratio of $R O E$ indicated the good performance of IRBI to get profit. Ratio of $E A$ has a significant negative influence on the level of NPF in IRBI in zone four. The results show us that the level of NPF can raise when ratio of $E A$ decreases. This indicated that IRBI in zone four could mitigate financing risks by improving efficiency.

The ratio of $R O E$ has a significant negative influence on the level of NPF in IRBI in zone four. The results show us that the level of $N P F$ can raise when the ratio $R O E$ decreases. This indicated that IRBIs in zone four need to increase the profitability in order to keep the minimal level of NPF.

Furthermore, the changes of macroeconomic variables like percentage of GDP and the inflation rate do not have an effect on IRBI in zone four, because the economic contribution to the national economy is relatively low. The Western region of Indonesia is a center of industry and trade is still centralized in the western region of Indonesia in order that the economic fluctuation have a small effect on the economy of the country.

Most of IRBIs in zone four are located in the Eastern region of Indonesia, which economically depends on sectors of agriculture and mining. Furthermore, infrastructure in the Eastern region of Indonesia is undeveloped compared with the Western region. Consequently, the fluctuations of macroeconomic indicators have a small effect on the economy of the Eastern region of Indonesia. 


\section{CONCLUSION}

The results of regression estimations are different in one to another zone. For instance, variables of bank size (LNTA), liquidity (FDR), efficiency (OER), percentage of GDP and rate of inflation simultaneously affect the level of NPF in IRBI in zone one. Meanwhile, variables of liquidity (FDR), efficiency (OER and $E A$ ) and percentage of GDP simultaneously affect the level of NPF in IRBI in zone two. Further, variables of bank size (LNTA) and percentage of GDP simultaneously affect the level of NPF in IRBI in zone three. Last, variables of liquidity $(F D R)$, efficiency $(E A)$, and profitability $(R O E)$ simultaneously affect the level of NPF in IRBI in zone four.

Based on the results of the study, government policy treatment should be different in every zone. For instance, most independent variables including bank specific factors and macroeconomic factors have a significant effect on the level of NPF in IRBI in zone one. Therefore the regulation for this zone must be tighter than for other zones, at least the quality of regulation must be equal to commercial banks. Meanwhile, zone two and zone three should be supported by the regulation which could improve performance of risk management and efficiency of IRBI. Further, the regulation for IRBI in zone four should be more free than other zones in order to improve the profitability performance. Nevertheless, the regulation for zone four should remain in the banking prudential principles.

\section{REFERENCES}

1. Berger, A. N., \& DeYoung, R. (1997). Problem loans and cost efficiency in commercial banks. Journal of Banking and Finance, 21(6), 849-870. https://doi.org/10.1016/S03784266(97)00003-4

2. Bloem, A. M., \& Gorter, C. N. (2001). The Treatment of Nonperforming Loans in Macroeconomic Statistitics (IMF Working Paper Series, WP/01/209).

3. Buchori, A., Himawan, B., Setijawan, E., \& Rohmah, N. (2003). Kajian Kinerja Industri BPRS Di Indonesia. Buletin Ekonomi Moneter Dan Perbankan, 5(4), 64-123.

4. Endut, R., Syuhada, N., Ismail, F., \& Mahmood, W. M. W. (2013). Macroeconomic implications on non-performing loans in Asian Pacific Region. World Applied Sciences Journal, 23(23), 57-60. https://doi.org/10.5829/idosi. wasj.2013.23.eemcge.22011

5. Espinoza, R., \& Prasad, A. (2010). Nonperforming Loans in the GCC Banking System and their Macroeconomic Effects (IMF Working Papers, 2010/224). https://doi. org/10.5089/9781455208890.001
6. Faiz, I. A. (2010). Ketahanan Kredit Perbankan Syariah terhadap Krisis Keuangan Global. La RIba: Jurnal Ekonomi Islam, 4(2), 217-237.

7. Firmansyah, I. (2014). Determinant of Non Performing Loan: the Case of Islamic Bank in Indonesia. Buletin Ekonomi Moneter Dan Perbankan, 17(2), 241-258. https://doi. org/10.21098/bemp.v17i2.51

8. Gujarati, D. (2003). Basic Econometrics. New York: McGraw-Hill Higher Education.

9. Klein, N. (2013). NonPerforming Loans in CESEE: Determinants and Impact on Macroeconomic Performance (IMF Working Paper Series, 2013/72). https://doi. org/10.5089/9781484318522.001

10. Louzis, D. P., Vouldis, A. T., \& Metaxas, V. L. (2012). Macroeconomic and bankspecific determinants of nonperforming loans in Greece: A comparative study of mortgage, business and consumer loan portfolios. Journal of Banking and Finance, 36(4), 1012-1027. https://doi.org/10.1016/j.jbankfin.2011.10.012
11. Schmidheiny, K. (2018). Panel Data: FIxed and Random Effects. Short Guides to Microeconometrics, Fall, 1-16. Retrieved from http:// schmidheiny.name/teaching/panel2up.pdf

12. Skarica, B. (2014). Determinants of non-performing loans in Central and Eastern European countries. Financial Theory and Practice, 38(1), 37-59. https://doi. org/10.3326/fintp.38.1.2

13. The World Bank. (2013). The New Microfinance Handbook. J. Ledgerwood (Ed.). Washington DC: The World Bank.

14. Zaini Abd Karim, M., Chan, S.-G., \& Hassan, S. (2010). Bank Efficiency and Non-Performing Loans: Evidence from Malaysia and Singapore. Prague Economic Papers, 19(2), 118-132. https://doi. org/10.18267/j.pep.367 